\title{
Patchwork of Land Ownership as Barrier to Development of Rural Areas**
}

\begin{abstract}
A patchwork of land ownership is one of the factors that exert negative influence on both the organization and level of agricultural production. Excessive land fragmentation decreases the intensity of agricultural practices and increases production costs, thus leading to a continuous reduction in income. Over the years, fields in many areas of Poland have been divided into smaller and smaller parcels, which has resulted in a faulty land ownership structure (along with a mass exodus of people to towns as well as abroad. This article presents a detailed study of the land ownership structure of fourteen villages situated in the commune of Bialaczów (district of the Opoczno and Łódź voivodeships). The aim of the article is to determine the intensification of the phenomenon of dispersion of farmland in the villages of the examined municipality using chessboard type tables.
\end{abstract}

Keywords: land consolidation, patchwork of fields, land exchange

* University of Life Sciences in Lublin, Department of Environmental Engineering and Geodesy, Lublin, Poland 


\section{Introduction}

Each region of Poland is characterized by specific features that exert direct influence on the rate of social and economic development in these areas. Land belonging to individual agricultural holdings located in central Poland (the Łódź voivodeship) is characterized by worse-than-average natural conditions for agricultural development. Yet, besides industry, agriculture is the main economic specialization of this region. In the Łódź voivodeship, small and very small agricultural holdings prevail (most with low productivity) [21]. A study [2] conducted in the villages of the commune of Slawno (located in the district of Opoczno) has shown that land belonging to individual agricultural holdings within villages is characterized by relatively small fragmentation, whereas land located in the external patchwork of fields poses a larger problem. In different regions of Poland, the size of the problem of the fragmentation of farmland belonging to an external patchwork of fields is different. The patchwork pattern of land ownership was discussed in detail by Rabczuk [20], who introduced the concept of non-resident owners. This concept was elaborated in the detailed studies of the problem of patchwork patterns of fields conducted by Noga [12-16] and Noga and Schilbach [18]. These issues have also been discussed in recent years by Dudzińska [1] and Gniadek [3]. Detailed studies concerning the external patchwork of fields belonging to individual agricultural holdings in southeastern Poland (Podkarpackie Voivodeship) have shown that the defects in the land ownership structure are very serious. For instance, in the villages in the district of Brzozow, every fourth parcel in the hands of private owners is located in an external patchwork of fields [5, 6]. In turn, in the village of Bedziemysl (situated in the Ropczyce-Sędziszow district), every fifth parcel is owned by outside-of-village non-resident owners [8]. In the village of Olszanica (located in the district of Lesko), $32.0 \%$ of the parcels are owned by outside-of-village non-resident owners, representing $36.0 \%$ of the total surface area of the village [7]. In the village of Konieczkowa (district of Strzyzow), $15.8 \%$ of the parcels are located in the external patchwork of fields; these parcels occupy as much as $17.7 \%$ of the total area of the village. In turn, in the village of Lutcza (district of Strzyzow), $19.9 \%$ of the parcels are owned by outside-of-village non-resident owners, representing $18.8 \%$ of the total area of the village [11]. As preliminary studies have shown, large areas of farmland located in an external patchwork of fields pose a very serious land management problem in the villages of central Poland. An analysis conducted in the villages of the commune of Slawno has shown that as much as $40.9 \%$ of the total surface area of those parcels belonging to individual agricultural holdings (i.e., $43.1 \%$ of the total number of privately-owned parcels) are located in the external patchwork of fields [9]. In the village of Brzustowiec (located in the commune of Drzewica), 26.9\% of the total number of parcels belonging to individual agricultural holdings are owned by outside-of-village non-resident owners; these parcels occupy $23.8 \%$ of the surface area of the privately-owned land in that village [10]. In the villages of eastern Poland 
(Lublin Voivodeship), just like in the area of central Poland, a large number of parcels belonging to individual agricultural holdings are located in an external patchwork of fields. As research conducted in the commune of Cycow (district of Łęczna) has shown, 4774 parcels in that commune belong to outside-of-village non-resident owners, a number that represents $46.1 \%$ of the privately-owned parcels in that commune. The surface area of farmland owned by individuals residing outside the analyzed commune is 5370.60 ha, which constitutes $43.6 \%$ of the entire surface area of the discussed commune. The number of all outside-of-village non-resident owners who possess land in the commune of Cycow is 2671. As shown by detailed studies, more than $40 \%$ of the parcels and more than $40 \%$ of the total area of privately-owned land in that commune are under control of outside-of-village non-resident owners [17]. In the village of Cycow alone, 211 proprietors (outside-of-village non-resident owners) own 317 cadastral plots occupying a surface area of 264.89 ha, which represents $28.6 \%$ of the total surface area of the village. 351 inhabitants of this village own 675 cadastral plots in the commune of Cycow, with a surface area of 874.42 ha [4].

Nowadays, it is recommended that measures be taken to eliminate both internal and external patchworks of farmland. Two such agricultural land management measures are land consolidation and land exchange. Rural areas in Poland require profound structural changes related to agricultural production, the size of agricultural holdings, and the distribution of farmland in an agricultural holding as well as the demographic, spatial, and institutional structure [20]. Land consolidation and land exchange not only result in better living and improved working conditions for farmers, but they also contribute to enhancing the environmental and cultural assets of a village. Agricultural land management interventions can play an important role in the protection of the environment and landscape, development of rural areas and agriculture, and maintenance of the traditions and cultural heritage. The fact that agricultural land management interventions bring both economic and environmental benefits is unquestionable [17].

As the first stage of the investigation, the research area was characterized, and data was collected from a land register. Then, the surface area of farmland owned by outside-of-village and local non-resident owners was determined for each village of the discussed area. In the third part of the study, the influence of municipal centers on the size of the external patchwork of fields in the discussed area was analyzed. To meet the aim set forth above, the distances of each village from the administrative center of the commune, the towns of Opoczno and Końskie, and the city of Łódź were determined. The pattern of ownership of land in the external patchwork of fields in terms of the distance of the farmland from the owner's place of residence was established by calculating the correlation coefficient for the distance of the villages from administrative, cultural, and services centers. The last stage of the study was devoted to determining the degree of land fragmentation of agricultural holdings in the villages of the discussed commune (using checkerboard tables) [16]. 


\section{Experimental}

\subsection{Analysis of External Patchwork of Privately-Owned Farmland}

In the analyzed commune (Tab. 1), outside-of-village non-resident owners own 2440.4 ha of farmland, which constitutes $33.7 \%$ of the total surface area of the land belonging to individual agricultural holdings. This area is divided into 5021 cadastral plots, which represent $34.5 \%$ of all of the privately-owned plots. The ownership of land in this area is divided among 2130 owners residing in the analyzed area and beyond its boundaries.

The surface areas of farmland belonging to non-resident owners are very different for the different villages [3]. In Kuraszkow (which ranks first in terms of the percentage of farmland belonging to outside-of-village owners), as much as $52.5 \%$ of privately-owned farmland is in the hands of people who do not live in that village. The next five villages in the ranking (with $40-50 \%$ of farmland belonging to outside-of-village non-resident owners) are Parczów (49.3\%), Ossa (47.8\%), Zakrzów (46.4\%), Wacglany (45.0\%), and Petrykozy $(42.7 \%)$. In a further five villages, the percentage share of the farmland owned by individuals residing outside these villages is within a range of $30-40 \%$ : Żelazowice $(39.7 \%)$, Sobień $(33.4 \%)$, Parczówek (33.2\%), Sędów (32.5\%), and Miedzna Drewniana (30.8\%). In Radwan, over one-fourth of privately-owned farmland belongs to outside-of-village non-resident owners. The lowest share of farmland held by outside-of-village non-resident owners was noted for the villages of Skronina (22.0\%) and Białaczów (13.4\%).

An analysis of the number of plots belonging to outside-of-village non-resident owners (Tab. 2) shows that, in two localities (Ossa and Kuraszków), more than 50\% (57.0 and 50.8\%, respectively) of all the plots belong to owners residing outside these villages. Next on the ranking list are three villages with the share of plots belonging to non-residents varying between 40 and 50\%: Parczów (45.7\%), Wąglany (42.3\%), and Żelazowice (40.4\%). Still lower on the list are the following villages with $30-40 \%$ of the plots belonging to non-resident owners: Petrykozy (38.7\%), Sobien $(37.5 \%)$, Zakrzów (37.4\%), and Parczówek (32.2\%). In a further five villages, the share of plots belonging to outside-of-village non-resident owners is below 30\%: Radwan (29.5\%), Miedzna Drewniana (29.4\%), Sędów (27.5\%), Białaczów (23.9\%), and Skronina (21.9\%).

Besides land belonging to outside-of-village non-resident owners, we also determined how much farmland belonged to local non-resident owners (i.e., owners from the commune of Białaczów - Tab. 2). As indicated by the data in Table 2, these individuals hold property rights to 442.6 ha of farmland, which constitutes $6.1 \%$ of the total surface area of the privately-owned land in the commune. This area is divided into 949 cadastral plots, which are owned by 461 people. The numbers of local non-resident owners and the surface area and numbers of plots belonging to them are different for the different villages (which is a consequence of the natural conditions associated with the geographical situation of the villages, transport conditions, and distances from localities that are administrative, cultural, and services centers). 
Table 1. Farmland belonging to outside-of-village non-resident owners in figures

\begin{tabular}{|c|c|c|c|c|c|c|c|c|c|c|c|c|c|}
\hline \multirow{3}{*}{ Name of village } & \multirow{2}{*}{\multicolumn{2}{|c|}{ Total surface area }} & \multirow{2}{*}{\multicolumn{2}{|c|}{ Plots }} & \multirow{2}{*}{\multicolumn{2}{|c|}{ Privately-owned farmland }} & \multirow{2}{*}{\multicolumn{2}{|c|}{$\begin{array}{l}\text { Number of privately-owned } \\
\text { plots }\end{array}$}} & \multicolumn{5}{|c|}{ Land belonging to outside-of-village non-resident owners } \\
\hline & & & & & & & & & \multirow{2}{*}{$\begin{array}{l}\text { Number of } \\
\text { owners }\end{array}$} & \multicolumn{2}{|c|}{ Surface area } & \multicolumn{2}{|c|}{ Plots } \\
\hline & ha & $\%$ & Number & $\%$ & ha & $\%$ & Number & $\%$ & & ha & $\%$ & Number & $\%$ \\
\hline Białaczów & 2214.9 & 19.3 & 2082 & 11.3 & 1150.0 & 51.9 & 1712 & 82.2 & 182 & 153.7 & 13.4 & 409 & 23.9 \\
\hline Kuraszków & 570.5 & 5.0 & 516 & 2.8 & 462.9 & 81.1 & 437 & 84.7 & 125 & 243.0 & 52.5 & 222 & 50.8 \\
\hline Miedzna Drewniana & 1057.5 & 9.2 & 1716 & 9.3 & 485.1 & 45.9 & 1428 & 83.2 & 132 & 149.3 & 30.8 & 420 & 29.4 \\
\hline Parczów & 804.6 & 7.0 & 1047 & 5.7 & 536.7 & 66.7 & 816 & 77.9 & 242 & 264.8 & 49.3 & 373 & 45.7 \\
\hline Parczówek & 725.9 & 6.3 & 2537 & 13.8 & 517.4 & 71.3 & 1804 & 71.1 & 155 & 171.5 & 33.2 & 580 & 32.2 \\
\hline Petrykozy & 518.7 & 4.5 & 736 & 4.0 & 418.2 & 80.6 & 600 & 81.5 & 161 & 178.5 & 42.7 & 232 & 38.7 \\
\hline Radwan & 364.7 & 3.2 & 761 & 4.1 & 334.1 & 91.6 & 647 & 85.0 & 67 & 87.3 & 26.1 & 191 & 29.5 \\
\hline Skronina & 1161.9 & 10.1 & 1664 & 9.0 & 654.7 & 56.4 & 1370 & 82.3 & 177 & 144.2 & 22.0 & 300 & 21.9 \\
\hline Sobień & 1022.3 & 8.9 & 1593 & 8.7 & 770.5 & 75.4 & 1144 & 71.8 & 100 & 257.7 & 33.4 & 429 & 37.5 \\
\hline Sędów & 437.4 & 3.8 & 1002 & 5.4 & 384.3 & 87.9 & 746 & 74.5 & 122 & 124.8 & 32.5 & 205 & 27.5 \\
\hline Waglany & 480.7 & 4.2 & 1581 & 8.6 & 388.7 & 80.9 & 1256 & 79.4 & 166 & 174.9 & 45.0 & 531 & 42.3 \\
\hline Zakrzów & 469.2 & 4.1 & 729 & 4.0 & 360.3 & 76.8 & 588 & 80.7 & 133 & 167.3 & 46.4 & 220 & 37.4 \\
\hline Żelazowice & 746.7 & 6.5 & 1774 & 9.6 & 632.7 & 84.7 & 1472 & 83.0 & 200 & 251.0 & 39.7 & 594 & 40.4 \\
\hline Ossa & 908.8 & 7.9 & 654 & 3.6 & 151.6 & 16.7 & 553 & 84.6 & 168 & 72.5 & 47.8 & 315 & 57.0 \\
\hline TOTAL: & 11483.6 & 100.0 & 18392 & 100.0 & 7247.4 & 63.1 & 14573 & 79.2 & 2130 & 2440.4 & 33.7 & 5021 & 34.5 \\
\hline
\end{tabular}

Source: prepared on basis of data from Land and Property Register of District Office in Opoczno 
Table 2. Size of farmland belonging to non-resident owners in villages of commune of Białaczów

\begin{tabular}{|c|c|c|c|c|c|c|c|c|c|c|c|c|c|c|c|c|c|c|c|c|c|c|c|c|c|c|c|c|c|c|}
\hline \multirow{5}{*}{$\dot{z}$} & \multirow{5}{*}{$\begin{array}{l}\text { Name of } \\
\text { village }\end{array}$} & \multirow{4}{*}{\multicolumn{2}{|c|}{$\begin{array}{c}\text { Farmland } \\
\text { belonging } \\
\text { to } \\
\text { individual } \\
\text { agricultural } \\
\text { holdings }\end{array}$}} & \multirow{4}{*}{\multicolumn{2}{|c|}{$\begin{array}{c}\text { Number of } \\
\text { privately-owned } \\
\text { plots }\end{array}$}} & \multicolumn{20}{|c|}{ Size of farmland belonging to outside-of-village non-resident owners } & \multirow{3}{*}{\multicolumn{5}{|c|}{$\begin{array}{l}\text { Size of farmland belonging to } \\
\text { local non-resident owners living } \\
\text { in the investigated area }\end{array}$}} \\
\hline & & & & & & \multirow{2}{*}{\multicolumn{4}{|c|}{$\begin{array}{l}\text { owners living in the } \\
\text { investigated area }\end{array}$}} & \multicolumn{12}{|c|}{ Owners living in urban localities } & \multirow{2}{*}{\multicolumn{4}{|c|}{$\begin{array}{c}\text { owners living outside the } \\
\text { investigated area }\end{array}$}} & & & & & \\
\hline & & & & & & & & & & \multicolumn{4}{|c|}{ Opoczno } & \multicolumn{4}{|c|}{ Łódź } & \multicolumn{4}{|c|}{ Końskie } & & & & & & & & & \\
\hline & & & & & & \multicolumn{2}{|c|}{$\begin{array}{c}\text { Surface } \\
\text { area }\end{array}$} & \multicolumn{2}{|c|}{ Plots } & \multicolumn{2}{|c|}{$\begin{array}{l}\text { Surface } \\
\text { area }\end{array}$} & \multicolumn{2}{|l|}{ Plots } & \multicolumn{2}{|c|}{$\begin{array}{l}\text { Surface } \\
\text { area }\end{array}$} & \multicolumn{2}{|l|}{ Plots } & \multicolumn{2}{|c|}{$\begin{array}{l}\text { Surface } \\
\text { area }\end{array}$} & \multicolumn{2}{|l|}{ Plots } & \multicolumn{2}{|c|}{$\begin{array}{l}\text { Surface } \\
\text { area }\end{array}$} & \multicolumn{2}{|l|}{ Plots } & \multirow{2}{*}{$\mid \begin{array}{c}\text { Number } \\
\text { of } \\
\text { owners }\end{array}$} & \multicolumn{2}{|c|}{$\begin{array}{c}\text { Surface } \\
\text { area }\end{array}$} & Plots & \\
\hline & & ha & $\%$ & Number & $\%$ & ha & $\%$ & Number & $\%$ & ha & $\%$ & Number & $\%$ & ha & $\%$ & Number & $\%$ & ha & $\%$ & Number & $\%$ & ha & $\%$ & Number & $\%$ & & ha & $\%$ & Number & $r$ \\
\hline 1 & Białaczów & 1150.0 & 51.9 & 1712 & 82.2 & 40.7 & 3.5 & 94 & 5.5 & 31.25 & 2.7 & 93 & 5.4 & 16.8 & 1.5 & 45 & 2.6 & 0.5 & 0.04 & 3 & 0.2 & 64.4 & 5.6 & 174 & 10.2 & 67 & 123.9 & 10.8 & 125 & 7.3 \\
\hline 2 & Kuraszków & 462.9 & 81.1 & 437 & 84.7 & 8.6 & 1.9 & 11 & 2.5 & 53.94 & 11.7 & 45 & 10.3 & 47.6 & 10.3 & 46 & 10.5 & 4.0 & 0.9 & 8 & 1.8 & 128.9 & 27.8 & 112 & 25.6 & 20 & 13.7 & 3.0 & 47 & 10,7 \\
\hline 3 & $\begin{array}{l}\text { Miedzna } \\
\text { Drewniana }\end{array}$ & 485.1 & 45.9 & 1428 & 83.2 & 22.9 & 4.7 & 84 & 5.9 & 25.68 & 5.3 & 76 & 5.3 & 9.4 & 1.9 & 27 & 1.9 & 4.9 & 1.0 & 11 & 0.8 & 86.2 & 17.8 & 222 & 15.5 & 47 & 33.2 & 6.8 & 108 & 7.6 \\
\hline 4 & Parczów & 536.7 & 667 & 816 & 77.9 & 60.6 & 11,3 & 80 & 9.8 & 26.97 & 5.0 & 47 & 5.8 & 9.9 & 1.8 & 17 & 2.1 & 2.4 & 0.4 & 5 & 0.6 & 165.0 & 30.7 & 224 & 27.5 & 27 & 19.5 & 3.6 & 64 & 7.8 \\
\hline 5 & Parczówek & 517.4 & 71.3 & 1804 & 71.1 & 37.2 & 7.2 & 144 & 8.0 & 37.71 & 7.3 & 134 & 7.4 & 14.7 & 2.8 & 29 & 1.6 & 7.2 & 1.4 & 27 & 1.5 & 74.7 & 14.4 & 246 & 13.6 & 26 & 16.7 & 3.2 & 33 & 1.8 \\
\hline 6 & Petrykozy & 418.2 & 80.6 & 600 & 81.5 & 46.0 & 11,0 & 43 & 7.2 & 37.59 & 9.0 & 61 & 10.2 & 4.3 & 1.0 & 11 & 1.8 & 6.1 & 1.5 & 11 & 1.8 & 84.5 & 20.2 & 106 & 17.7 & 51 & 49.3 & 11.8 & 131 & 21,8 \\
\hline 7 & Radwan & 334.1 & 91.6 & 647 & 85.0 & 18.3 & 5.5 & 48 & 7.4 & 17.65 & 5.3 & 30 & 4.6 & 2.7 & 0.8 & 10 & 1.5 & 0.0 & 0.0 & 0 & 0.0 & 48.6 & 14.6 & 103 & 15.9 & 12 & 10.2 & 3.1 & 26 & 4.0 \\
\hline 8 & Skronina & 654.7 & 56.4 & 1370 & 82.3 & 39.0 & 6.0 & 84 & 6.1 & 21.05 & 3.2 & 43 & 3.1 & 14.6 & 2.2 & 27 & 2.0 & 3.1 & 0.5 & 7 & 0.5 & 66.6 & 10.2 & 139 & 10.1 & 69 & 52.9 & 8.1 & 103 & 7.5 \\
\hline 9 & Sobień & 770.5 & 75.4 & 1144 & 71.8 & 32.3 & 4.2 & 74 & 6.5 & 5.91 & 0.8 & 14 & 1.2 & 58.1 & 7.5 & 80 & 7.0 & 13.9 & 1.8 & 25 & 2.2 & 147.6 & 19.2 & 236 & 20.6 & 18 & 31.8 & 4.1 & 68 & 5.9 \\
\hline 10 & Sędów & 384.3 & 87.9 & 746 & 74.5 & 24.0 & 6.2 & 35 & 4.7 & 7.77 & 2.0 & 17 & 2.3 & 2.1 & 0.5 & 5 & 0.7 & 16.4 & 4.3 & 25 & 3.4 & 74.6 & 19.4 & 123 & 16.5 & 31 & 28.9 & 7.5 & 73 & 9.8 \\
\hline 11 & Wagglany & 388.7 & 80.9 & 1256 & 79.4 & 25.1 & 6.5 & 105 & 8.4 & 62.71 & 16.1 & 177 & 14.1 & 14.9 & 3.8 & 46 & 3.7 & 1.5 & 0.4 & 2 & 0.2 & 70.7 & 18.2 & 201 & 16.0 & 39 & 28.6 & 7.4 & 60 & 4.8 \\
\hline 12 & Zakrzów & 360.3 & 76.8 & 588 & 80.7 & 60.0 & 16,7 & 70 & 11,9 & 8.59 & 2.4 & 6 & 1.0 & 28.7 & 8.0 & 31 & 5.3 & 3.6 & 1.0 & 4 & 0.7 & 66.4 & 18.4 & 109 & 18.5 & 32 & 16.1 & 4.5 & 52 & 8.8 \\
\hline 13 & Żelazowice & 632.7 & 84.7 & 1472 & 83.0 & 25.8 & 4.1 & 69 & 4.7 & 66.65 & 10.5 & 146 & 9.9 & 23.7 & 3.7 & 72 & 4.9 & 9.0 & 1.4 & 17 & 1.2 & 125.9 & 19.9 & 290 & 19.7 & 21 & 14.9 & 2.4 & 56 & 3.8 \\
\hline 14 & Ossa & 151.6 & 16.7 & 553 & 84.6 & 2.3 & 1.5 & 8 & 1.4 & 8.94 & 5.9 & 42 & 7.6 & 19.9 & 13.1 & 83 & 15.0 & 0.4 & 0.3 & 6 & 1.1 & 40.9 & 27.0 & 176 & 31.8 & 1 & 2.9 & 1.9 & 3 & 0.5 \\
\hline & Razem: & 7247.4 & 78.2 & 14573 & 79.2 & 442.6 & 6.1 & 949 & 6.5 & 412.45 & 5.7 & 931 & 6.4 & 267.43 & 3.7 & 529 & 3.6 & 72.848 & 1.0 & 151 & 1.0 & 1245.1 & 17.2 & 2461 & 16.9 & 461 & 442.6 & 6.1 & 949 & 6.5 \\
\hline
\end{tabular}




\subsection{Influence of Urban Localities on Non-Resident Land Ownership}

Apart from farmland belonging to non-resident owners living in the commune of Białaczów, much of the farmland in the investigated area is owned by individuals residing in villages outside the commune and in urban localities. This has been caused by the fact that many people from the commune of Białaczów have found employment in other towns in the Łódź voivodeship as well as towns and cities in neighboring voivodeships. In general, outside-of-village non-resident owners from outside the investigated area own as much as 1245.1 ha of the commune's farmland (17.2\% of the total surface area of the commune).

The distance between the investigated villages and urban localities was measured on a map in a straight line from town/city to the central point of the built-up area of a village. A matrix of distances between the investigated towns/cities (Opoczno, Łódź, Końskie) and the villages from where the non-resident owners originated was created. Two matrices were used to calculate the correlation coefficient. The statistically significant values of the coefficient showed that the urban localities had an effect on the degree of the patchwork of farmland. The impact of the towns/cities on the size of farmland belonging to outside-of-village non-resident owners was confirmed by an analysis of the influence of urban centers offering different grades of administrative, industrial, cultural, and educational services. Data regarding the impact of three urban centers of the Łódź voivodeship on the size of farmland belonging to outside-of-village non-resident owners are provided in Table 3, and the spatial distribution of this impact is shown in Figure 1. The data in the table indicates that the town of Opoczno only affects the pattern of farmland ownership within a range of $11.3 \mathrm{~km}$ due to its administrative function (district town) as well as its commercial and cultural-educational functions (with town-dwellers owning farmland in villages of the investigated commune). Within this radius, there are only 6 villages (out of the 14 villages studied) in which farmland is owned by inhabitants of Opoczno.

Preliminary results showed that, like in the case of Opoczno, inhabitants of Końskie owned farmland in 13 villages of the commune of Białaczów. The correlation coefficient indicated that the range of influence on farmland ownership for Końskie was $14.7 \mathrm{~km}$. This range encompassed five localities situated in the southeastern part of the commune.

Inhabitants of the city of Łódź (the capital of the voivodeship) owned farmland in 14 villages in the commune of Białaczów. However, regularities in the pattern of farmland ownership by proprietors from this urban center, identified by a significant correlation coefficient, were observed for only six of the villages. These villages are located within a distance of $93.5 \mathrm{~km}$ (Białaczów) to $106 \mathrm{~km}$ (Parczówek) from Łódź. As the map of the spatial distribution of land ownership shows, the city of Łódź exerts the strongest influence on the villages located in the northwestern and central parts of the analyzed area. 


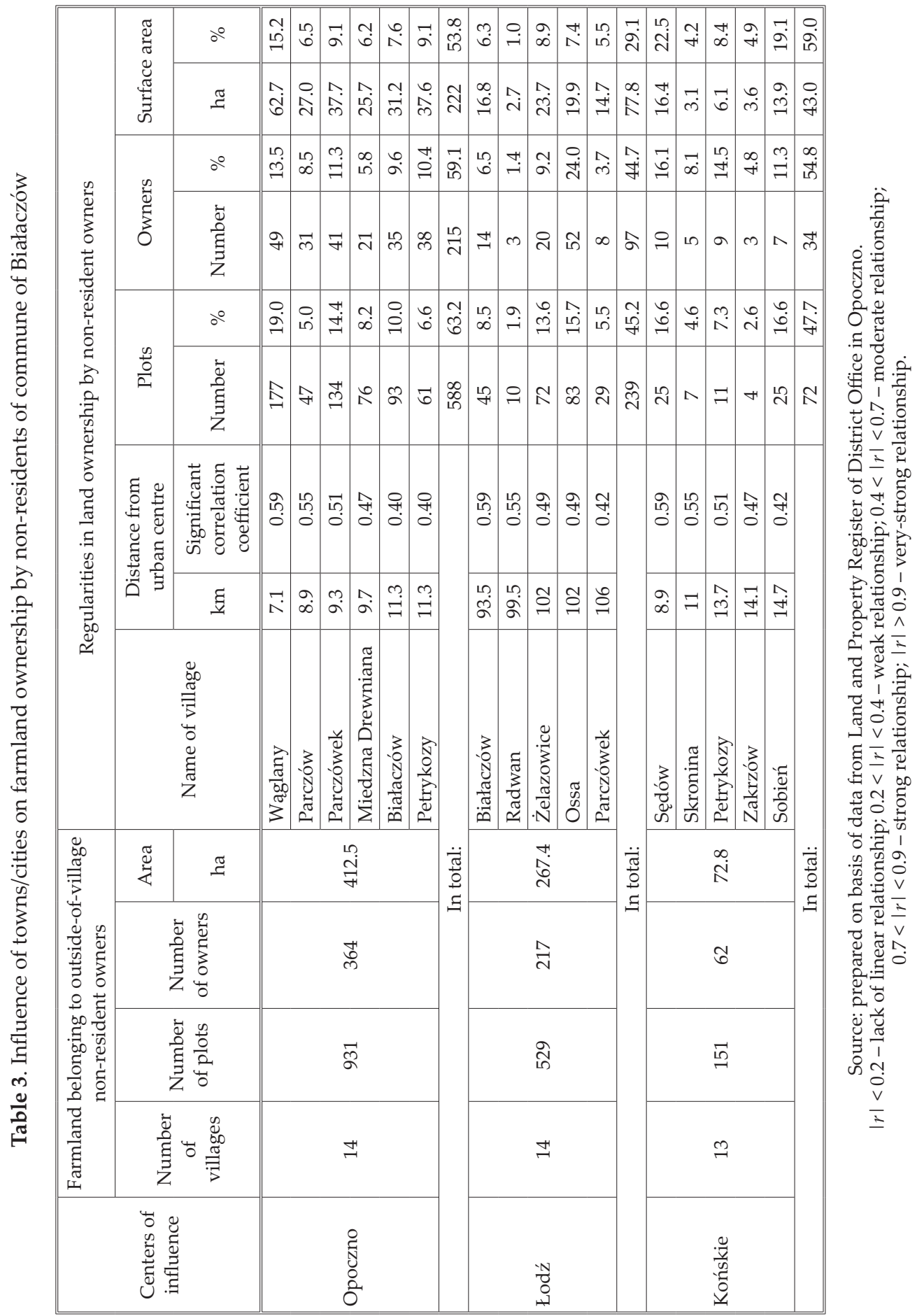


The spatial image showing regularities in the structure of farmland ownership by non-resident owners (Fig. 1) indicates that the land belonging to non-resident owners is concentrated in those areas of the commune that have easy access to the analyzed towns.

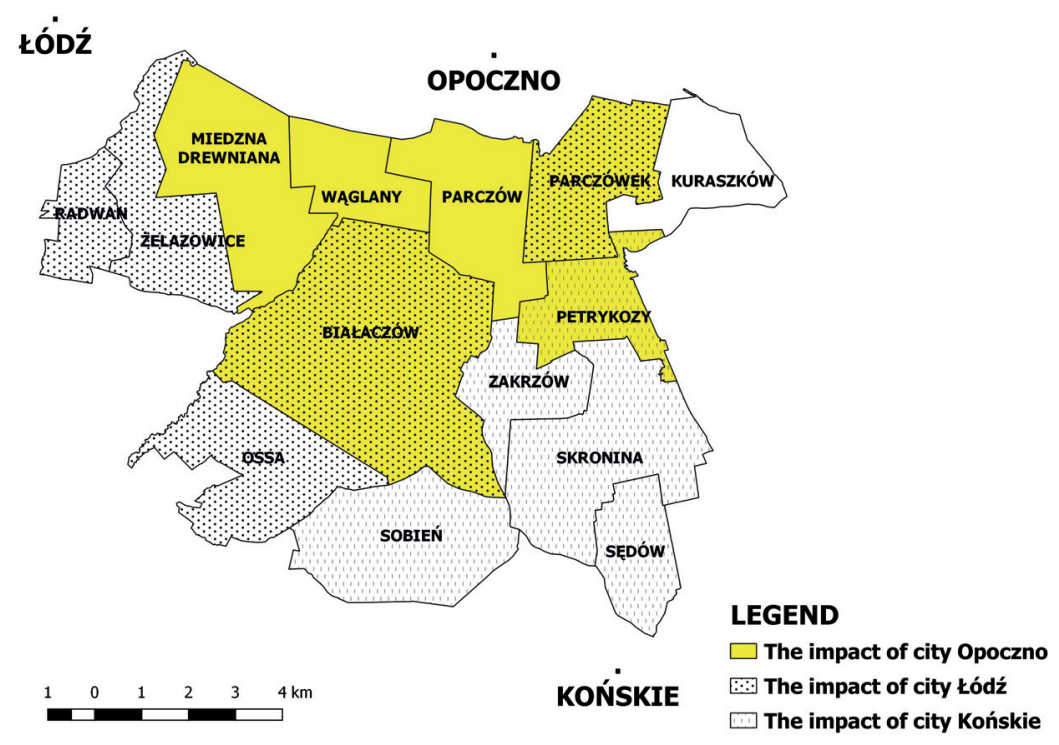

Fig. 1. Spatial distribution of influence of towns

\subsection{Size of Farmland Belonging to Non-Resident Owners in Commune of Białaczów}

The use of checkerboard tables [16] in the analysis and assessment of the patchwork pattern of land ownership allows one to create a matrix of any degree for one or several villages or an entire commune, depending on the territorial scope of the patchwork of fields. To obtain an information matrix, it is first necessary to specify the area to be examined. Next, data concerning the total surface area, structure of arable land, number of plots, and number of non-resident owners must be obtained from a land register. A separate matrix is developed for each of the above categories (pieces of information). Since it is not the case that there are parcels of land in each village belonging to owners from every other village under study, a lack of data is marked as " 0 " (zero) in the matrix. The obtained matrix is ordered so that the highest values are situated along the diagonal, which allows one to identify the areas of greatest concentration of checkerboard farmland. An ordered matrix makes it possible to determine not only the above-mentioned regularities but also the degree of fragmentation and scope of the patchwork of the fields (both between villages and subsets of villages and for an entire commune). By using this method for viewing, 
balancing, and analyzing a patchwork of fields, one can establish the degree of land fragmentation in the agricultural holdings [13]. Detailed data is shown in Table 4, and spatial images of the clustering of villages are presented in Figures 2 and 3.

Table 4. Matrix of patchwork of farmland in commune of Białaczów

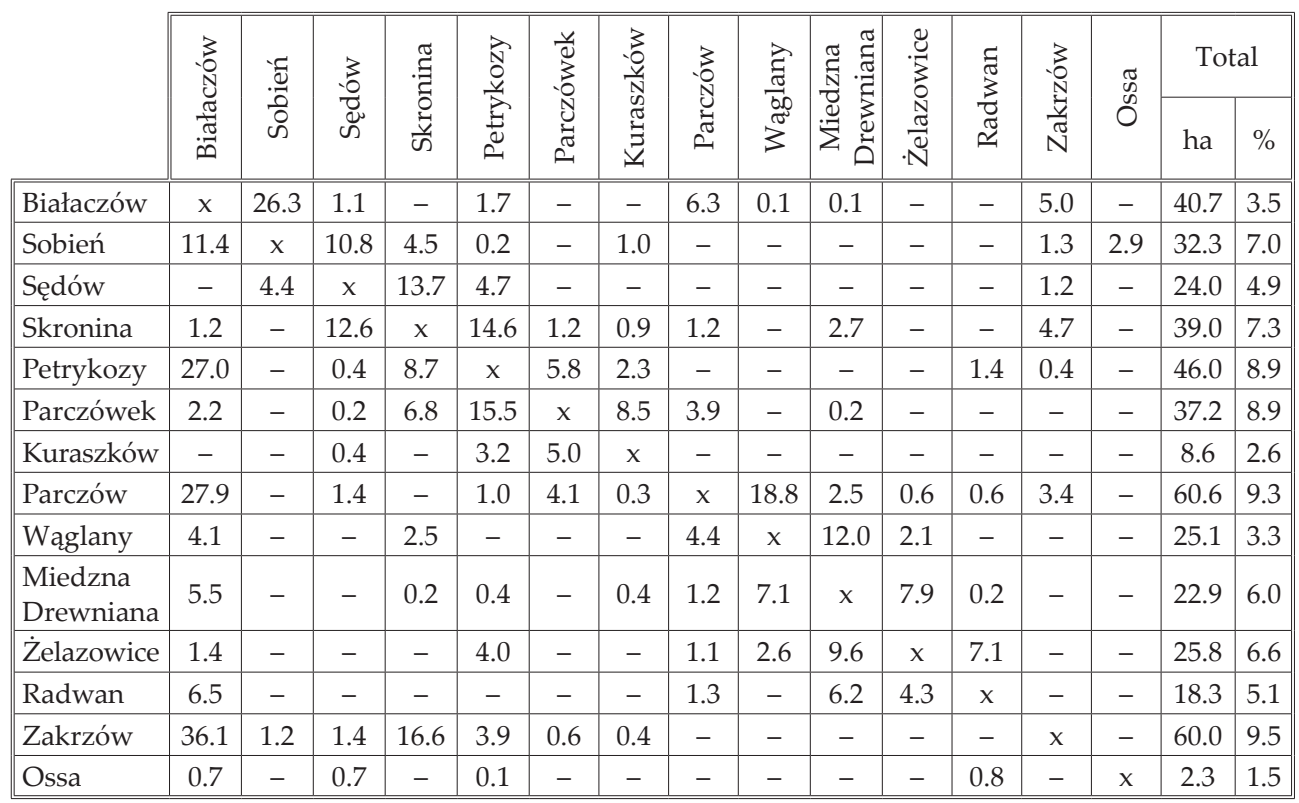

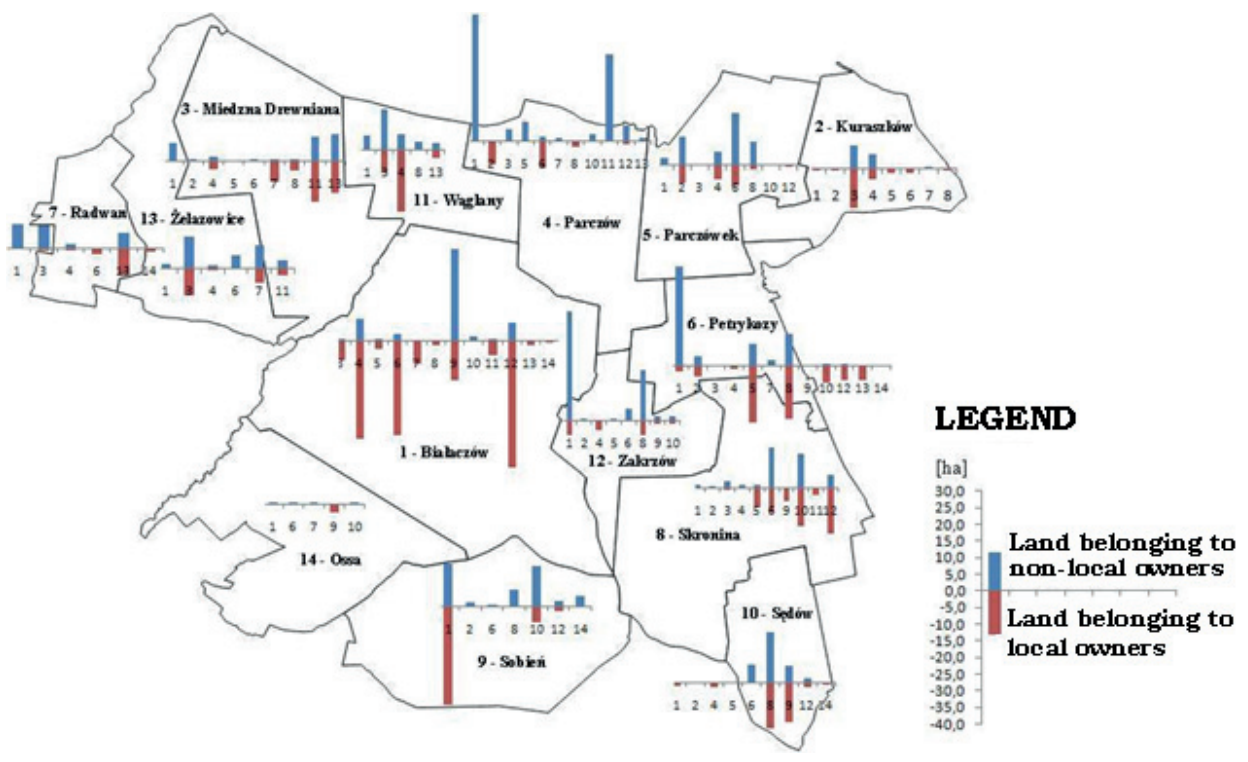

Fig. 2. Spatial image of clustering of villages in commune of Białaczów 


\section{LEGEND}

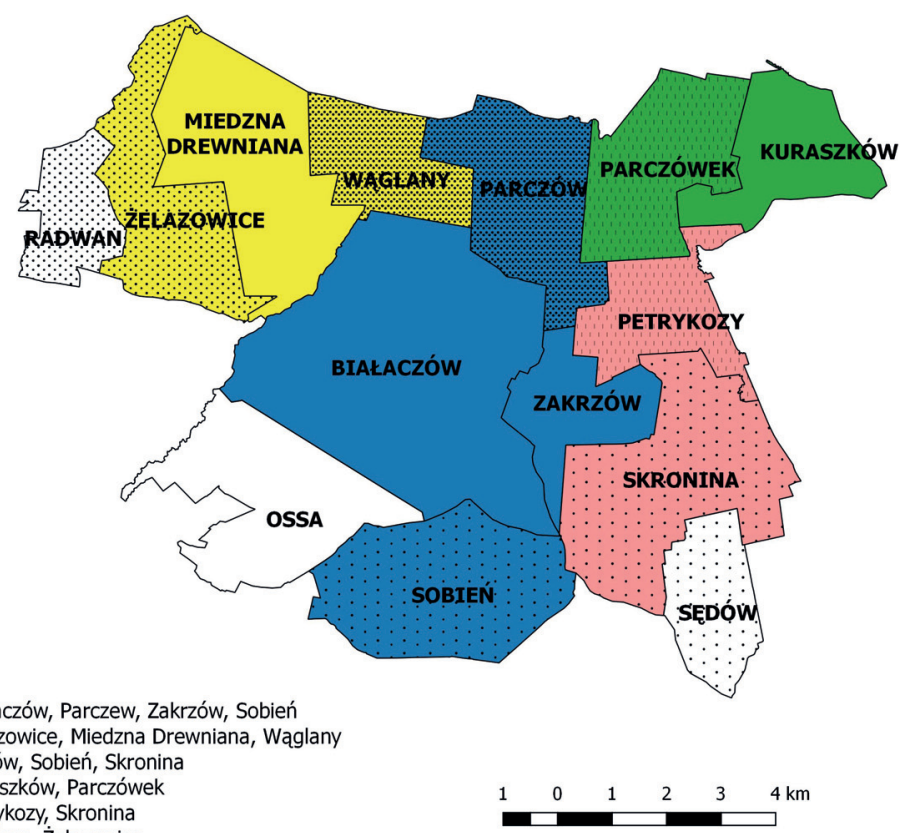

Grouping village: Białaczów, Parczew, Zakrzów, Sobień

Grouping village: Żelazowice, Miedzna Drewniana, Wąglany

. Grouping village: Sędów, Sobień, Skronina

Grouping village: Kuraszków, Parczówek

Grouping village: Petrykozy, Skronina

$\because$ Grouping village: Radwan, Żelazowice

Grouping village: Wagglany, Parczów

$\square$ Grouping village: Parczówek, Petrykozy

Fig. 3. Spatial image of clustering of villages in commune of Białaczów

The method of checkerboard tables allowed us to clearly determine the degree of land fragmentation in the villages of the discussed commune. On the basis of the obtained matrix, we can accurately determine the surface area of land that could be consolidated or for which an exchange program could be developed (Tab. 4). As the results show, there are regularities concerning the clustering of villages: both around the municipality of Białaczów (Parczów, Zakrzów, Sobień) and neighboring villages (Sobień-Skronina-Sędów or Żelazowice-Miedzna Drewniana-Waglany).

The present study confirmed that the commune of Białaczów had a faulty land ownership structure involving an external patchwork of fields. Nowadays, it is necessary that measurements are taken to eliminate such faulty patchwork patterns, with a view to improve and develop agricultural production as well as the working and living conditions in rural areas. One solution to the above-mentioned problem is the exchange of land among local and outside-of-village non-resident owners.

\section{Conclusions}

The fact that a large part of farmland in the investigated area belongs to non-resident owners is the result of inheritance, trading in land, or arranged marriages. Apart from land belonging to non-resident owners who live in the commune of 
Białaczów, large areas of farmland in the commune belong to individuals from outside this rural community (chiefly inhabitants of towns and cities), which is a result of the location of the commune in central Poland. The geographical situation of Białaczów is conducive to the mass migration of people from the analyzed villages to different places around the country and abroad. The analysis showed that a large number of outside-of-village non-resident owners were inhabitants of Łódź (the seat of the voivodeship authorities), Opoczno (district town), and Końskie (district town directly adjacent to the Opoczno district). A significant number of inhabitants from the villages emigrated to Warsaw, Piotrków Trybunalski, Radom, Kielce, and many other towns and cities. Inhabitants of these localities own land in most of the villages of the analyzed commune. They are mostly people who left the villages in order to find better employment or who inherited land from their parents. Some of the plots have been adapted/purchased for construction or recreation purposes, since the analyzed area is very attractive in terms of tourism. The characteristic feature of the land belonging to outside-of-village non-residents is that it is concentrated around a main village (the seat of a commune or parish), which points to the existence of cultural and religious relationships (one parish is comprised of several to a dozen or so villages). In the past, young people who met in the main village of the commune settled down in that place after marriage. The large area of land in the hands of individuals living outside the commune of Białaczów suggests that the land owned by them is either not used at all or is informally leased to inhabitants of the commune.

For consolidation of such a large external patchwork of land as the one in the commune of Białaczów to be accomplished successfully, a land exchange program must first be implemented and completed (since it is difficult to consolidate land in the entire area of the commune). Land exchange will considerably decrease the distance between land belonging to owners from other villages in the analyzed commune and the farm homestead. Land that cannot be brought closer to the homestead for the time being is land belonging to inhabitants of towns, since exchange of that land requires additional studies and analyses that will allow us to solve the problem in a reasonable way. The present study shows that there is an urgent need for the development of land-exchange technology followed by the implemention of a comprehensive consolidation program.

\section{References}

[1] Dudzińska M.: Szachownica gruntów rolnych jako czynnik kształtujący przestrzeń Wiejską. Infrastruktura i Ekologia Terenów Wiejskich, no. 2012/02, 2012, pp. 45-56.

[2] Głowienka E., Leń P.: Zastosowanie metod GIS w analizie struktury przestrzennej obszarów wiejskich gminy Sławno w powiecie opoczyńskim. Czasopismo Inżynierii Lądowej, Środowiska i Architektury, z. 63, nr 3, 2016, pp. 227-238. 
[3] Gniadek J.: Ocena przestrzennego ukształtowania działek różniczan na przykładzie Mściwojowa. Infrastruktura i Ekologia Terenów Wiejskich. no. 2013/02, 2012, pp. 133-143.

[4] Król Ż., Leń P.: Szachownica gruntów indywidualnych wyznacznikiem pilności wykonania prac scalenia i wymiany gruntów. Infrastruktura i Ekologia Terenów Wiejskich, no. II/1, 2016, pp. 311-322.

[5] Leń P.: Prawidłowości w rozmiarze występowania gruntów różniczan zamiejscowych na przykładzie wsi w powiecie Brzozów. Infrastruktura i Ekologia Terenów Wiejskich, no. 01, 2012, pp. 137-145.

[6] Leń P.: Rozmiary gruntów różniczan i możliwości ich likwidacji (na przykładzie wsi w powiecie Brzozów, województwo podkarpackie). [in:] XVII Ogólnopolska Konferencja "Nowe tendencje w teorii i praktyce urządzania obszarów wiejskich" na temat "Rozwój obszarów wiejskich - stan obecny i perspektywy", Puławy 24-26.06.2009. Materiały publikowane, pp. 73-78.

[7] Leń P., Dzhyadosh D., Kovalyshyn O.: Vykorystannya prohramy Quantum GIS pid chas analizu prostorovoyi struktury sela Ol'Shanytsya [День П., Джядош Д., Ковалишин О.: Використання програми Quantum GIS під час аналізу просторової структури села Ольшаниця]. Seriya: Ekonomika APK, no. 22 (2), 2015, pp. 151-158, [on-line] irbis-nbuv.gov.ua [access: 25.11.2016].

[8] Leń P., Matysek I., Kovalyshyn O.: Dimensions of Plots Belonging to Out-of vil-lage Owners in the Village of Będziemyśl, Commune of Sędziszów Małopolski. Geomatics and Environmental Engineering, vol. 9, no. 2, 2015, pp. 63-70.

[9] Len P., Mika M.: Determination of the urgency of undertaking land consolidation works in the villages of the Stawno municipality. Journal of Ecological Engineering Volume 17, Issue 4, Sept. 2016a, pp. 163-169.

[10] Leń P., Mika M.: The impact of socio-economic factors on the size of the external plot patchwork on the example of Brzustowiec village, in the Eódzkie Voivodship. Geomatics and Environmental Engineering, vol. 10, no. 2, 2016, pp. 43-51.

[11] Leń P., Mika M., Wójcik-Leń J.: Estimation of the size of the external land patchwork based on test areas in Podkarpackie Voivodship in Poland. Geomatics, Landmanagement and Landscape, no. 1. 2016, pp. 65-74.

[12] Noga K.: Analiza międzywioskowej szachownicy gruntów na przykładzie wsi położonych w górnym dorzeczu Soły. Zeszyty Naukowe Akademii Rolniczej, nr 133, Sesja Naukowa, no. 7, Akademia Rolnicza, Kraków 1977, pp. 153-170.

[13] Noga K.: Metodyka programowania i realizacji prac scalenia i wymiany gruntów w ujęciu kompleksowym. Szkoła Wiedzy o Terenie, Akademia Rolnicza, Kraków 2001.

[14] Noga K.: Metodyka programowania prac scaleniowych i technologia ich wykonywania w terenach górskich (na przykładzie beskidzkiej zlewni Soły). Zeszyty Naukowe Akademii Rolniczej im. H. Kołłątaja w Krakowie: Rozprawa Habilitacyjna, nr 143, Akademia Rolnicza, Kraków 1990. 
[15] Noga K.: Możliwości likwidacji szachownicy zewnętrznej gruntów. Prace Naukowe Politechniki Warszawskiej. Geodezja, z. 26, 1985, pp. 231-237.

[16] Noga K.: Problematyka likwidacji międzywioskowej szachownicy gruntów. [in:] Nowe tendencje scalania gruntów indywidualnych w terenach wyżynnych, górzystych i górskich. Tom I, IUNG, Puławy, 1985, pp. 143-166.

[17] Noga K., Król Ż.: The Patchwork of Land as a Problem Restricting the Development of Rural Areas. Barometr Regionalny, t. 14, nr 3, 2016, pp. 155-163.

[18] Noga K., Schilbach J.: Metodyka przekształcania wadliwej struktury przestrzennej rolnictwa w terenach górskich. Zeszyty Naukowe Akademii Rolniczo-Technicznej w Olsztynie, nr. 22, 1998, pp. 153-161.

[19] Rabczuk I.: Problem różniczan w pow. proszowickim,woj. krakowskie. [in:] Aktualne zagadnienia geodezji urzadzeniowo rolnej, Wydawnictwo Czasopism Technicznych NOT, Warszawa 1968, pp. 65-70.

[20] Sobolewska-Mikulska K.: Metodyka rozwoju obszarów wiejskich z uwzględnieniem wybranych procedur geodezyjnych w aspekcie integracji z Unia Europejska. Prace Naukowe Politechniki Warszawskiej, Geodezja, nr 44, 2009, pp. 3-148.

[21] Strategia rozwoju województwa łódzkiego na lata 2007-2020, on-line: http:// www.strategia.lodzkie.pl/index.php?option=com_content\&view=article\&id=15\&Itemid $=15$ [access: 20.03 .2017$]$.

\section{Szachownica gruntów barierą rozwoju obszarów wiejskich}

Streszczenie: Szachownica gruntów jest jednym z istotnych czynników wywierających ujemny wpływ zarówno na organizację, jak i poziom produkcji rolniczej. Nadmierne rozproszenie gruntów zmniejsza intensywność prac oraz zwiększa koszty produkcji rolniczej, co z kolei powoduje, że uzyskiwane dochody są coraz niższe. Przestrzenne układy gruntów indywidualnych wsiach na przestrzeni wieków ulegały ciągłym podziałom, z kolei duża migracja ludzi doprowadziło do powstania wadliwej zewnętrznej szachownicy gruntów. W artykule szczegółowo przeanalizowano układy przestrzenne gruntów indywidualnych w czternastu wsiach gminy Białaczów, położonej w powiecie opoczyńskim, w województwie łódzkim. Celem artykułu jest określenie nasilenia zjawiska rozproszenia gruntów gospodarstw rolnych we wsiach badanej gminy przy zastosowaniu tablic typu szachownicowego.

\section{Słowa}

kluczowe: scalenie gruntów, szachownica gruntów, wymiana gruntów 